Article

\title{
Floral Volatiles from Vigna unguiculata Are Olfactory and Gustatory Stimulants for Oviposition by the Bean Pod Borer Moth Maruca vitrata
}

\author{
Bo Feng ${ }^{1}$, Kai Qian ${ }^{1}$ and Yong-Jun Du ${ }^{1,2, *}$ \\ 1 Institute of Health and Environmental Ecology, Wenzhou Medical University, University Town, \\ Wenzhou 325035, Zhejiang, China; fb@wmu.edu.cn (B.F.); qk@wmu.edu.cn (K.Q.) \\ 2 Institute of Pesticide and Environmental Toxicology, Zhejiang University, 866 Yuhangtang Rd., \\ Hangzhou 310058, Zhejiang, China \\ * Correspondence: yongjundu@zju.edu.cn; Tel.: +86-571-88982517
}

Academic Editor: Brian T. Forschler

Received: 8 March 2017; Accepted: 6 June 2017; Published: 9 June 2017

\begin{abstract}
We investigated the role of floral odors from cowpea, Vigna unguiculata (L.), in mediating oviposition of the bean pod borer moth, Maruca vitrata, a serious pest of grain legumes that flies to host plants at the flowering stage and oviposits onto flowers and buds. The flower of the host plant $V$. unguiculata was a stimulus for egg-laying by $M$. vitrata in an oviposition bioassay. Commercial longifolene, $\beta$-caryophyllene, linalool, geraniol, and ( $Z$ )-3-hexenyl acetate were used as stimulus. Each one elicited dose-dependent electroantennogram responses in female $M$. vitrata, and all but longifolene stimulated oviposition, when presented singly. Beta-caryophyllene was the most active stimulant, similar to that of the flower of $V$. unguiculata, and eliciting a dose-dependent oviposition response. Either olfaction or gustation was sufficient to mediate an oviposition response to $V$. unguiculata floral volatiles: intact $M$. vitrata responded to $\beta$-caryophyllene whether or not they could contact the source of the volatiles, and females with amputated antennae responded if allowed to contact the source. We believe this is the first demonstration in a moth where $\beta$-caryophyllene from the host plant was able to mediate an oviposition response. As $\beta$-caryophyllene is widely expressed by non-host plants, we suggest that its role in stimulating oviposition could be exploited as part of a push-pull strategy for pest management in which $\beta$-caryophyllene-expressing non-host plants provide a population sink for $M$. vitrata.
\end{abstract}

Keywords: floral odor; $\beta$-caryophyllene; Maruca vitrata; oviposition; Vigna unguiculata

\section{Introduction}

Phytophagous Lepidoptera use a hierarchy of semiochemical cues to locate host plants and to determine their suitability for oviposition, followed with a sequence of behavior that involves searching, orientation, encountering, landing, surface evaluation, and acceptance [1-3]. Much research has been focused on the role of antennal olfactory receptors for plant volatiles, including floral odors, which enables orientation and movement towards the host plant from a distance [4,5]. By contrast, after an insect alights on a plant, contact perception of its physical and chemical characteristics will become paramount in determining the plant's suitability for oviposition. Fewer volatile secondary plant metabolites are recognized by contact chemoreceptors, usually on the insect's ovipositor, tarsi, or mouth parts [6]. Host plant compounds that stimulate oviposition have been found in several moth species [7-9], and a range of chemicals such as pyrrolizidine alkaloids [10] and (-)-germacrene D [11] have been identified as stimulants.

The bean pod borer, Maruca vitrata (Fabricius) (Lepidoptera, Crambidae), is oligophagous on legumes in the tropics and subtropics, and is a serious pest of grain legumes $[12,13]$. Newly emerged 
adult $M$. vitrata fly to host plants during the flowering or budding stage. Females usually oviposit onto flower buds or flowers [14], allowing the larvae to cause severe feeding damage to flower buds, flowers, and developing bean pods [15]. M. vitrata often distributes eggs singly on the flowers of the cowpea, Vigna unguiculata (L.) Walp. The flowers provide abundant nutrition to the adult, which in turn contributes to ovary and egg development [16]. In West Africa, $M$. vitrata appears to migrate from the south to the north over the course of several months, a movement most likely explained by the phenology of flowering of leguminous trees [17].

Floral scent often plays a key role in acting as a selective attractant to plants, particularly where floral morphology itself does not impose selection on flower visitors [18]. Male and female moths are attracted to flowers as food sources. The importance of floral odor cues in this behavior is well documented among noctuid pest species $[19,20]$. In addition, some studies reported the effect of flower scent on the oviposition of moths, such as Helicoverpa armigera [21,22] and Heliothis virescens [23]. Given the close association of the life history of $M$. vitrata with the flowering of its host plants, floral volatiles could play an important role in host location and selection, as has been found in the pollen beetle, Meligethes aeneus (Fab.), a temperate pest of the buds and flowers of oilseed rape Brassica napus L. [24]. Evidence from laboratory experiments show that the larvae of $M$. vitrata are attracted more to host flowers as opposed to pods $[25,26]$. Indeed, as far as we are aware, research on the effect of flower scent on oviposition in Lepidoptera is rare and lacking. Studies have been focused more on the role of less volatile secondary metabolites of host and non-host plants detected by contact chemoreception $[27,28]$. The volatiles emanating from host crops of $M$. vitrata have been studied, and they play a key role in the mating behavior of $M$. vitrata possibly by augmenting sex responses in both sexes [29]. However, the effect of floral odors on oviposition behavior in M. vitrata remains unknown. Indeed, as far as we are aware, research on the effect of flower scent on initiating moth's oviposition in Lepidoptera is rare and lacking.

The number of compounds in the volatiles of cowpea flower was about 109 and they were classified into six categories on the basis of biosynthetic origin: aliphatics, aromatics, monoterpenes, sesquiterpenes, norisoprenoids, and other miscellaneous compounds that were present, but did not share any striking similarities [30]. Of these volatiles linalool, $\beta$-caryophyllene and geraniol are widespread compounds of floral scents and have been reported in flower of many plant taxa, including many legume species [31]. These three volatiles were found to be important factors in the pollination of flowers by bees [32-34], flower thrips [35], garden chafer [36], and hummingbirds [37]. In the present study, specific floral volatiles known from literature were used to investigate the role of cowpea floral odor in mediating oviposition by M. vitrata. Longifolene is a known floral volatile in Amaryllidaceae, Araceae, Musaceae, and Rosaceae [31] and has been found in flowers of $V$. unguiculata in our extracts. (Z)-3-Hexenyl acetate is one of the most abundant compounds in the bean leaf (Lwande et al. 1989) and was also reported in cowpea floral volatiles [30]. Both longifolene and (Z)-3-hexenyl acetate were used in our study to determine if they could mediate oviposition by M. vitrata.

The specific objectives of the work described here were (1) to investigate the role of floral odor from the cowpea, $V$. unguiculata in mediating oviposition of $M$. vitrata; (2) to evaluate the compounds in the floral odor responsible for oviposition; (3) to assess the roles of olfaction and gustation in sensing these compounds; (4) to underpin the future development of semiochemically based technologies for control of this pest.

\section{Methods and Materials}

\subsection{Insects}

Cowpea pods with Maruca vitrata larvae were collected from cowpea plants from the fields in Ouhai, Wenzhou, China, from June to October in 2009-2011, and they were placed in plastic cups with a $250 \mathrm{~mL}$ volume. Plastic cup was covered with a square gauze $(15 \mathrm{~cm} \times 15 \mathrm{~cm})$ and placed in a climate chamber $(8 \mathrm{~m} \times 3 \mathrm{~m} \times 3 \mathrm{~m})$ at $25 \pm 1{ }^{\circ} \mathrm{C}, 75 \pm 5 \%$ relative humidity, and 14:10 $\mathrm{h}(\mathrm{L}: \mathrm{D})$ photoperiod. 
Plastic cups were checked daily to monitor the emergence of $M$. vitrata moths. Male and female moths were separated immediately after eclosion according to the morphology of the abdominal tip [38]. Adults were kept in screen cages $(30 \mathrm{~cm} \times 25 \mathrm{~cm} \times 25 \mathrm{~cm}$ ) and fed a $10 \%$ glucose aqueous solution that was replaced daily.

\subsection{Plants}

From June 2009 to August 2011, V. unguiculata was sown in an experimental field (4 m $\times 4 \mathrm{~m})$ near the Chashan campus of Wenzhou Medical University. Seeds were planted in groups of three, with each group being separated by a length of $30 \mathrm{~cm}$. When the plants grew to a height of about $50 \mathrm{~cm}$, those infested with pests were removed. A wooden frame $(4 \mathrm{~m} \times 4 \mathrm{~m} \times 2 \mathrm{~m})$ covered with white gauze (size of mesh about $1 \mathrm{~mm}$ ) was set up around the plants to prevent pest infestation. The use of pesticides and other agrochemicals was prohibited to avoid contaminating and altering the volatiles taken off from the plants. To provide nutrients for the plant growth, standard organic vegetable food was used before sowing, at a plant height of about $30 \mathrm{~cm}$, and after flowering.

\subsection{Commercial Chemicals Used as Stimuli}

Linalool, geraniol, longifolene, and (Z)-3-hexenyl acetate were purchased from Sigma-Aldrich (St Louis, MO, USA), $\alpha$-caryophyllene and $\beta$-caryophyllene from Tokyo Chemical Industry Co., Ltd. (Tokyo, Japan), and paraffin oil from Tianjin Kemiou Chemical Reagent Co., Ltd. (Tianjin, China). The purity of all chemicals was greater than $97 \%$. Linalool, geraniol, longifolene, (Z)-3-hexenyl acetate, and $\beta$-caryophyllene were diluted with paraffin oil to concentrations $10^{-1}, 10^{-2}, 10^{-3}$, $10^{-4}$, and $10^{-5}(\mathrm{~V} / \mathrm{V})$. A synthetic blend was made from equal parts of those five diluted chemicals $\left(10^{-1}\right.$ concentration).

\subsection{Electroantennogram (EAG) Recording}

Recordings of whole-antenna electrical activity in response to volatile stimuli were made according to the standard technique described by Yan [39]. Antennae for EAG recordings were amputated from the head at their base. After removing the terminal segment, antennae were attached to each side of a two-pronged electrode "fork" recording probe (base of antenna at the ground position) using a small amount of electrode gel. The recording probe was connected to the pre-amplifier of a Syntech EAG recording system. From there, signals were transmitted to an oscilloscope for monitoring and through a Syntech signal acquisition controller, IDAC-2, to a computer for recording and analysis using Syntech EAG 2000 software. Stimuli were presented by introducing odoriferous air into a continuous air stream $(1200 \mathrm{~mL} / \mathrm{min})$ cleaned by activated charcoal, humidified by passage through water, and directed at the antenna through a Pasteur pipette. Odors were introduced in air passed through a glass dropper containing a $30 \mathrm{~mm} \times 4 \mathrm{~mm}$ strip of filter paper impregnated with $10 \mu \mathrm{L}$ of a solution of the test compound in paraffin oil. For each stimulus, a $0.1 \mathrm{~s}$ air puff of odoriferous air (air flow $40 \mathrm{~mL} / \mathrm{min}$ ) was delivered into a hole in the Pasteur pipette carrying the clean air stream. To avoid sensory adaptation, there was at least a $30 \mathrm{~s}$ lapse between two stimuli. Five concentrations $\left(10^{-1}, 10^{-2}, 10^{-3}, 10^{-4}\right.$, and $\left.10^{-5}\right)$ of linalool, geraniol, longifolene, (Z)-3-hexenyl acetate, and $\beta$-caryophyllene were used in the experiment. Antennae from six mated female moths were tested for every concentration of each chemical. Paraffin oil was used as control, and its EAG response was subtracted from the test compound. As the response of antennae declined during the course of the experiment, a $1 \%$ concentration $(\mathrm{V} / \mathrm{V})$ of $(\mathrm{Z})$-3-hexenyl acetate was used as a reference. Responses of antennae to all tested chemicals were standardized with response to the reference.

\subsection{Dissection of Reproductive System}

One- to three-day-old female moths were anaesthetized with $\mathrm{CO}_{2}$, and the abdomens were removed. The reproductive system was dissected in PBS solution under a microscope. Photos were taken with Nikon SMZ1500. 


\subsection{Moth Copulation}

Eight pairs of male and female moths of the same age were introduced into the screen cage and allowed to freely move around and mate. Copulation was monitored every night (19:00-06:00) using a digital handy camera (DCR-TRV27, SONY, Tokyo, Japan) with a super night shot. Mating pairs were transferred to a cylindrical plastic cup. Three- to five-day-old mated females were used for the oviposition bioassay in the following morning. Five replicates were conducted.

\subsection{Effect of Host Plant Flower on Oviposition}

A mated female was transferred to a plastic cup with a $250 \mathrm{~mL}$ volume, which was covered with a piece of gauze $(15 \mathrm{~cm} \times 15 \mathrm{~cm})$ to prevent the female moth escaping. Two fresh-cut healthy flowers of $V$. unguiculata with the stems in a small $(10 \mathrm{~mL})$ cup with fresh water inside the big cup were used as the oviposition stimulus. A plastic cup without any flower (blank group) was used as a control. Each moth was fed with a $10 \%$ glucose solution that was maintained with absorbent cotton. Eggs laid in the $250 \mathrm{~mL}$ cup, the $10 \mathrm{~mL}$ cup, the absorbent cotton, and the gauze were counted daily under a stereomicroscope. The glucose solution, flowers of $V$. unguiculata, and plastic cups were replaced daily $(17: 00 \mathrm{~h})$ until the moth died. Ten mated moths were used for each treatment as ten replicates.

\subsection{Effect of Components of V. unguiculata Floral Volatiles on Oviposition}

To test the effect of components of $V$. unguiculata floral volatiles on oviposition, $20 \mu \mathrm{L}$ of diluted linalool, geraniol, (Z)-3-hexenyl acetate, longifolene, and $\beta$-caryophyllene $\left(10^{-1}\right.$ concentration) with paraffin oil, or their synthetic blend with the same volume was placed on a filter paper $(30 \mathrm{~mm} \times 10 \mathrm{~mm})$, which was hung as the oviposition stimulus. Paraffin oil $(20 \mu \mathrm{L})$ placed on the double-folded filter paper was used for control. A mated female was maintained in a $250 \mathrm{~mL}$ plastic cup and fed with 10\% glucose solution as before. Eggs laid in the cup, on the filter paper, on the absorbent cotton, and on the gauze were counted twice a day (06:00 $\mathrm{h}$ and 17:00 $\mathrm{h}$ ), and food, stimulus, and plastic cup were replaced daily $(17: 00 \mathrm{~h})$ until the moth died. In addition, $\alpha$-caryophyllene and $\beta$-caryophyllene $\left(10^{-1}\right.$ concentrations) were used as stimulus, but eggs were counted daily. Ten mated moths were used for each treatment as ten replicates.

\subsection{Effect of Concentrations of $\beta$-Caryophyllene on Oviposition}

To test the effect of concentrations of $\beta$-caryophyllene on oviposition, $20 \mu \mathrm{L}$ portions with different concentrations of $\beta$-caryophyllene $\left(10^{-1}, 10^{-3}\right.$, and $10^{-5}$ concentrations) diluted with paraffin oil was placed on a filter paper $(30 \mathrm{~mm} \times 10 \mathrm{~mm})$, and the double-folded filter paper was hung as the oviposition stimulus. Paraffin oil $(20 \mu \mathrm{L})$ placed on the double-folded filter paper was used for control. Either a mated or unmated female was maintained in a plastic cup and fed with $10 \%$ glucose solution as before. All eggs were counted, and the food, stimulus, and plastic cup were replaced daily (17:00 h) until the moth died. Ten mated moths were used for each treatment as ten replicates.

\subsection{Testing the Roles of Olfaction and Gustation in the Reception of $\beta$-Caryophyllene}

The filter paper $(30 \mathrm{~mm} \times 10 \mathrm{~mm})$ with $20 \mu \mathrm{L}$ of $\beta$-caryophyllene with a $10^{-1}$ concentration was either hung directly in the oviposition cup as before ('with contact' treatment) or placed into a $2 \mathrm{~mL}$ Eppendorf tube, which was punctured with 100 holes each $0.50 \mathrm{~mm}$ in diameter was hung in the oviposition cup ('without contact' treatment). For the 'non-antennae' treatment, the antennae were cut at the base with scissors under stereomicroscope, while the female moth was anaesthetized on ice, and for the 'antennae' treatment, the antennae were left as is on the moth. There were 4 combinations for the stimulus and mated female: contact $\times$ non-antennae, non-contact $\times$ non-antennae, non-contact $\times$ antennae, and contact $\times$ antennae. Paraffin oil $\times$ antennae was used as control. The anaesthetized and mated female (with or without antennae) was maintained in a plastic cup and fed with $10 \%$ glucose solution as before. Eggs laid in the $250 \mathrm{~mL}$ cup, and on the filter paper (the Eppendorf tube), 
the absorbent cotton, and the gauze, were counted daily, and the food, stimulus, and plastic cup were replaced daily $(17: 00 \mathrm{~h})$ until the moth died. Ten mated moths were used for each treatment as ten replicates.

\subsection{Data Analysis}

Statistical analysis was conducted using SPSS17.0. One-way analysis was used to determine the variance for raw data with three or more treatments. If variances were homogeneous, then multiple comparisons using Duncan' test was used. If variances were non-homogeneous, then Tamhane's T2 test was performed to analyze significant differences between the data. Data from two treatments were analyzed by a Student's $t$-test. The critical $p$-value for each test was set at 0.05 .

\section{Results}

\subsection{Egg Maturation and Female Mating Frequency by Age}

The ovary of $M$. vitrata was long and eggs in the ovary were nearly all transparent at adult emergence (Figure 1A). After feeding, yolk formation was accelerated and eggs became opaque because of the light scattering from the yolk (Figure 1B). Some mature eggs were found in three-day-old females (Figure 1C). Although a few moths were mating at two days old, the copulation of most M. vitrata started on Day 3 or later (Figure 1D), at which times the ovaries of mated females were mature.
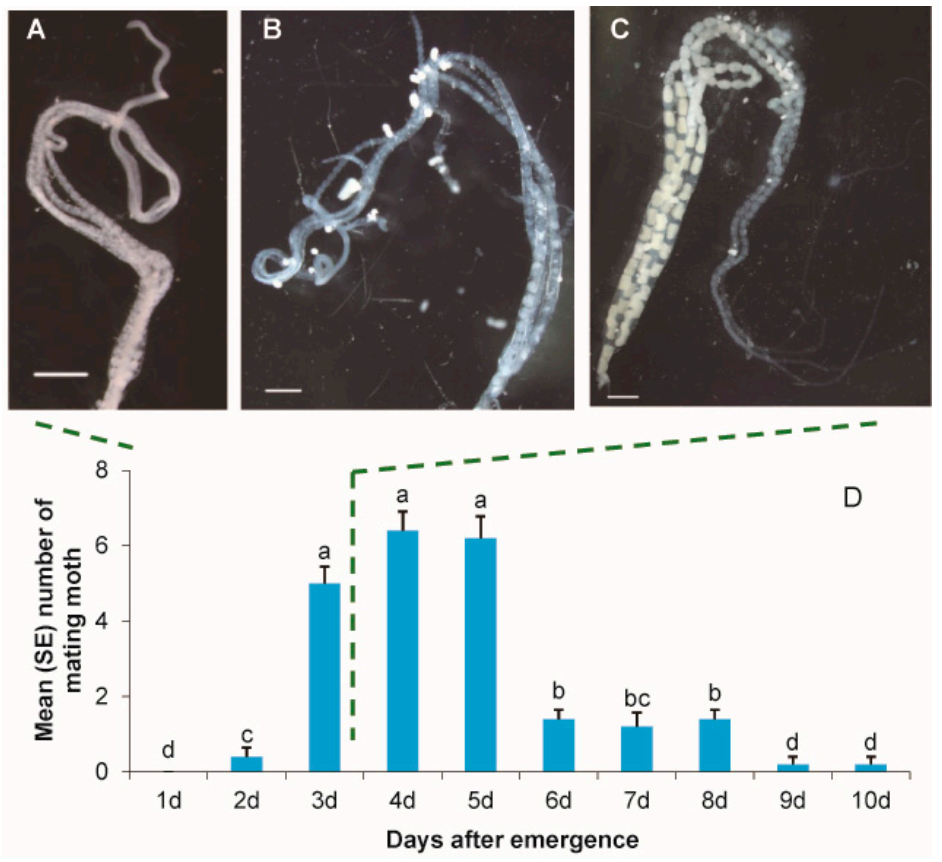

Figure 1. Egg maturation and female mating frequency by age. (A-C) The ovary of 1-, 2-, and 3-day-old females; scale in lower left is equal to $2.0 \mathrm{~mm}$. After feeding, the ovary gradually developed in the body, and there were some mature eggs in ovaries of 3-day-old females. (D) The mean number of moth pairs observed copulating each day (means with the same latter are not significantly different; $p>0.05$, one-way ANOVA with Duncan' test). Error bars signify SE. Nearly all moths copulated at the age of 3 days or older.

\subsection{Oviposition by Age with and without Flowers Present}

The flower of the host plant $V$. unguiculata was the stimulus for egg-laying in the oviposition bioassay (Figure 2). From the third day after copulation, the number of eggs laid by the moths exposed to host flowers was evidently increased. In contrast, females in the control group (blank group) laid a 
few eggs every day, and the number of eggs was unchanged even 12 days after copulation (Figure 2). Female exposed to host flowers laid significantly more eggs than those in the control (blank) group from the fourth days ( $p \leq 0.006$, except Day 7 ). The host flower stimulated oviposition by mature females, but ovary and egg development proceeded in the same way for all females whether with or without flowers in the chamber.

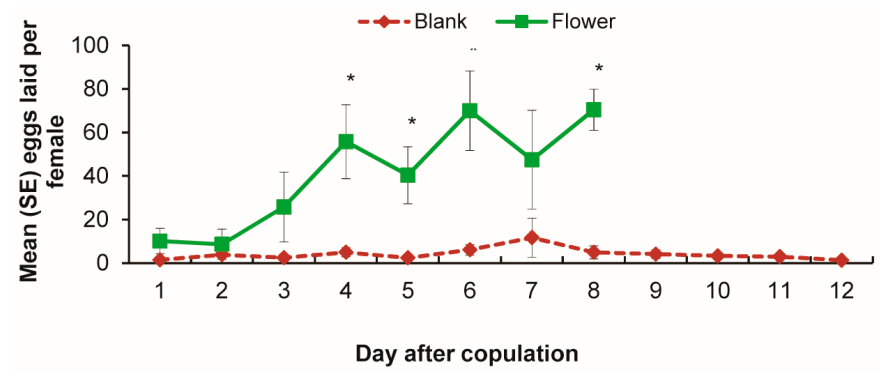

Figure 2. Oviposition by age with and without flowers present. Error bars signify SE. Significance of difference between blank and flower treatment indicated by " $*$ ", $p<0.05$, Student's $t$-test. From the third day after copulation, the number of eggs laid by the moths exposed to host flowers was greater than those in blank group.

\subsection{EAG Responses of Female Antennae to Components of V. unguiculata Floral Volatiles}

Female antennae showed evident EAG responses to commercial preparations of five components identified in the floral volatiles of $V$. unguiculata presented in paraffin oil. Significant decreases were found for the moth response when these chemicals were gradually diluted with paraffin oil $(p<0.05$; Figure 3). However, decreased rates of moth response were diversified for these chemicals. Significant decreases were found in linalool and geraniol with $10^{-3}$ and $10^{-4}$ concentrations, in $\beta$-caryophyllene with $10^{-2}$ to $10^{-4}$ concentrations, and in longifolene and (Z)-3-hexenyl acetate with every diluted concentration $(p \leq 0.014)$. Slopes and regression values of EAG responses as a function of concentration testing for linalool, geraniol, $\beta$-caryophyllene, longifolene, and (Z)-3-hexenyl acetate were -0.117 $\left(R^{2}=0.898\right),-0.187\left(R^{2}=0.954\right),-0.364\left(R^{2}=0.869\right),-0.270\left(R^{2}=0.865\right)$, and $-0.464\left(R^{2}=0.955\right)$, respectively. Although the response to linalool was significantly smaller than $\beta$-caryophyllene and (Z)-3-hexenyl acetate with a $10^{-1}$ concentration, it was still significantly larger than other chemicals at low concentrations $\left(10^{-4}\right.$ and $\left.10^{-5}\right)(p<0.001)$.

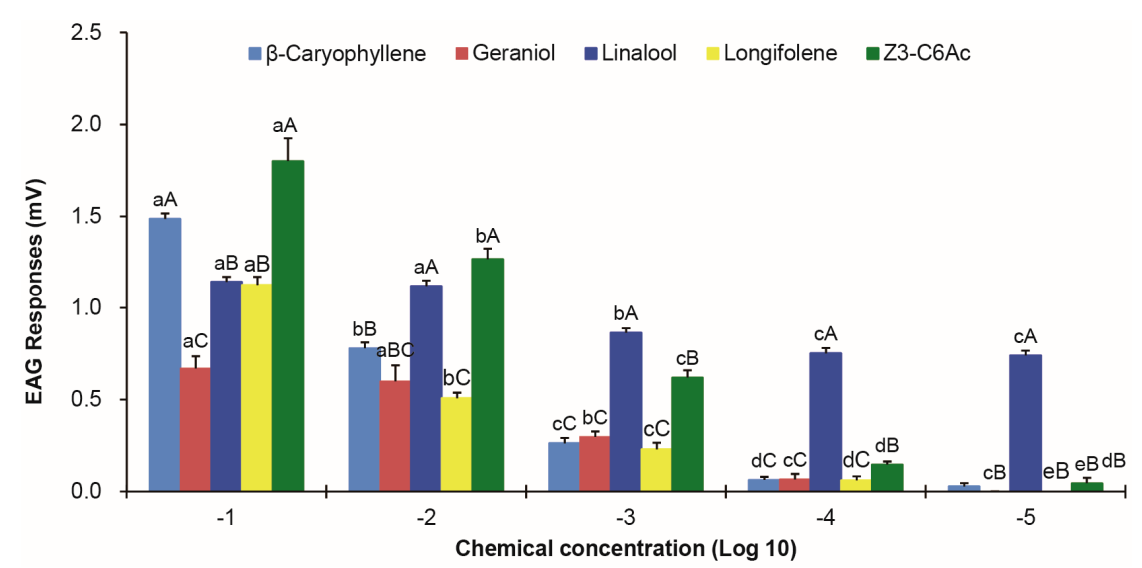

Figure 3. Mean electroantennogram responses recorded from female M. vitrata antennae elicited by $10 \mu \mathrm{L}$ of a paraffin oil solution of floral volatiles at decreasing concentrations. Error bars signify SE. Significance among different concentrations of the same volatile and among different volatiles of the same concentration are indicated by lower case and upper case letters, respectively. Means are significantly different if followed by a different letter ( $p<0.05$, one-way ANOVA with Duncan' test). 


\subsection{V. unguiculata Floral Volatiles as Stimuli on Female Oviposition}

Four components of V. unguiculata floral volatiles- $\beta$-caryophyllene, geraniol, linalool, and (Z)-3-hexenyl acetate-significantly stimulated egg-laying of $M$. vitrata when compared to paraffin oil controls ( $p \leq 0.001$; Figure 4A). The egg-laying response to $\beta$-caryophyllene was not only the most rapid, but also the strongest. All eggs were laid within the first eight days of the bioassay (Figure 4B). For the other three oviposition-stimulating chemicals, egg-laying responses were not evidently different from each other, with the exception of the (Z)-3-hexenyl acetate between the 8th and 11th day. Within these days, egg-laying stimulated by (Z)-3-hexenyl acetate was more than that by the geraniol and linalool (Figure 4B). The effect of isomers of caryophyllene on the oviposition was the same (Figure $4 \mathrm{C}$ ). Longifolene did not stimulate egg-laying of $M$. vitrata compared to the control (Figure 4A).
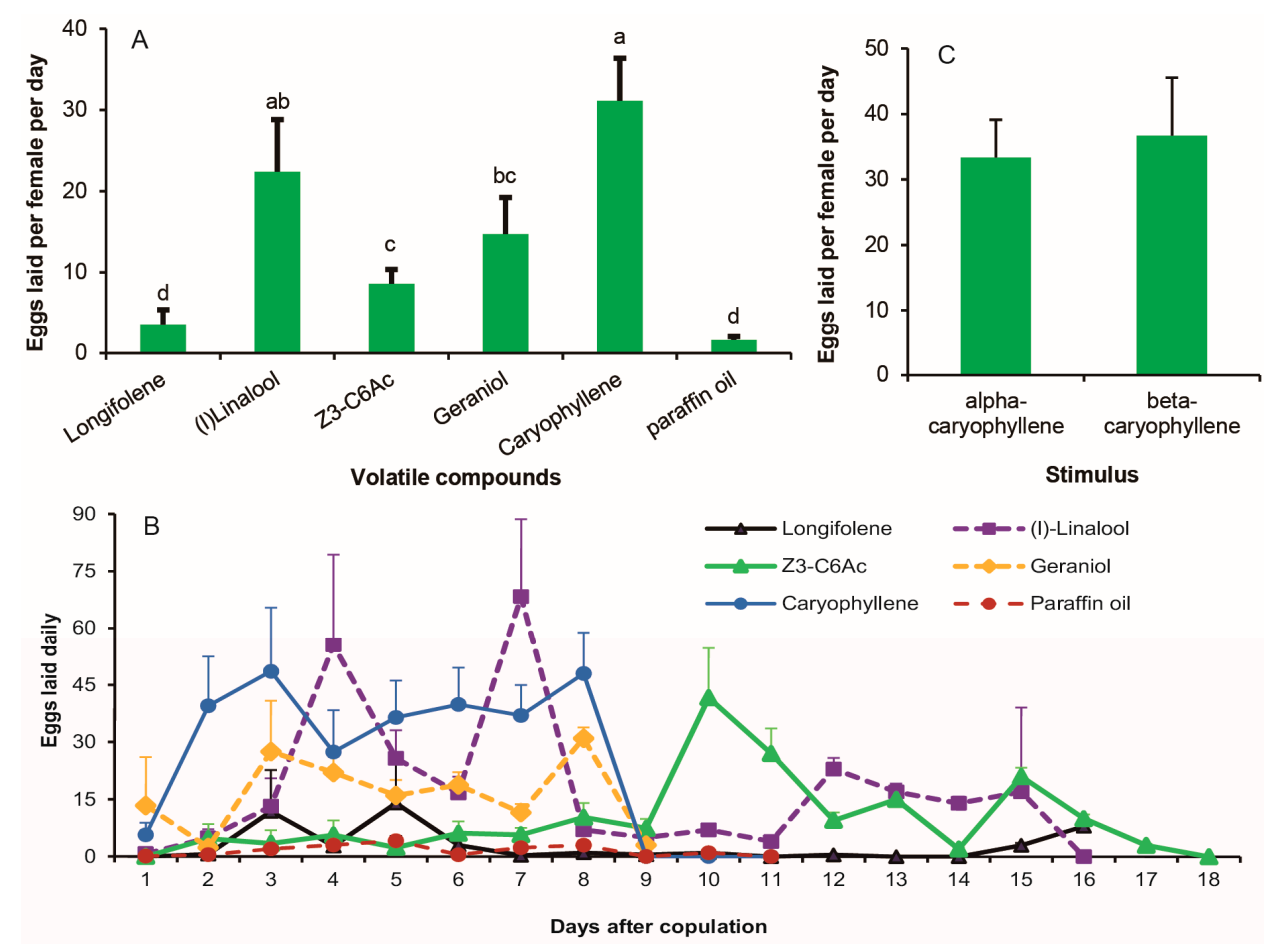

Figure 4. Vigna unguiculata floral volatiles as stimuli on female oviposition of M. vitrata. (A) The number of eggs laid per female per day elicited by $20 \mu \mathrm{L}$ of a paraffin oil solution of floral volatiles applied to paper. (B) The number of eggs laid every day after copulation. Caryophyllene with the strongest stimulation on female oviposition for tested volatiles. (C) Oviposition stimulation of isomer of Caryophyllene. Error bars signify SE. Significance among different volatiles are indicated by lower case letters. Different letter means significant difference ( $p<0.05$, one-way ANOVA with Duncan' test).

\subsection{Stimulation of Host Floral Volatiles on Female Oviposition Restricted in Night}

Females in control (paraffin oil) group laid very few eggs with no difference between night and day. After being exposed to host floral volatiles (except longifolene), females laid significantly more eggs at night than during the day $(p \leq 0.011)$. The number of eggs laid at night was significantly greater than that of the control (paraffin oil) group, when the mated females were exposed to $\beta$-caryophyllene, linalool, and the blend $(p \leq 0.023)$. For example, the number of eggs increased 14 times for $\beta$-caryophyllene treatment at night ( $p=0.005$; Figure 5). However, the number of eggs laid during the day was not significantly increased after host floral volatiles treatment $(p=0.169)$. 


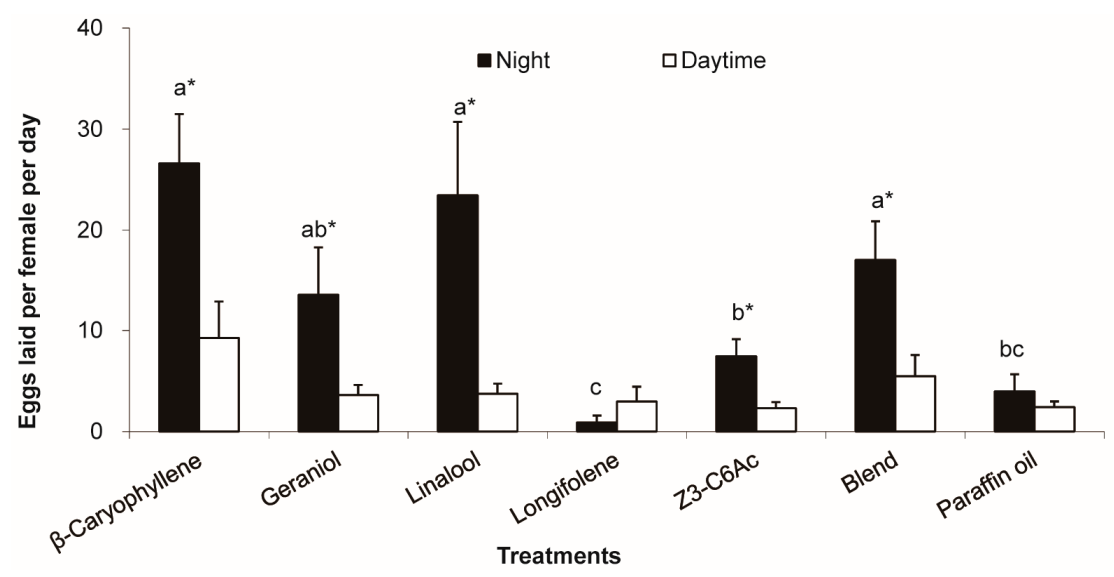

Figure 5. Eggs laid during the day (06:00-17:00 h) and the night (17:00-06:00 h) by female M. vitrata elicited by $20 \mu \mathrm{L}$ of a paraffin oil solution of floral scents applied to paper. Error bars signify SE. Significance among different volatiles and between night and daytime indicated by lower case letters and "*". Different letter and "*" means significant difference ( $p<0.05$, one-way ANOVA with Duncan' test for different volatiles and Student's $t$-test for night and daytime).

\subsection{Stimulation of $\beta$-Caryophyllene on Female Oviposition as Strong as Flower}

Female oviposition from $\beta$-caryophyllene was as strong as that from two flowers $(p=0.582$; Figure 6A). However, the synthetic blend of all five main components of $V$. unguiculata volatiles was significantly less active in the oviposition bioassay than that of the two $V$. unguiculata flowers $(p=0.047$; Figure 6A). The oviposition stimulation of $\beta$-caryophyllene was faster than that of $V$. unguiculata flowers, but the oviposition stimulation of the synthetic blend was delayed and weaker when compared to the stimuli from flowers (Figure 6B).
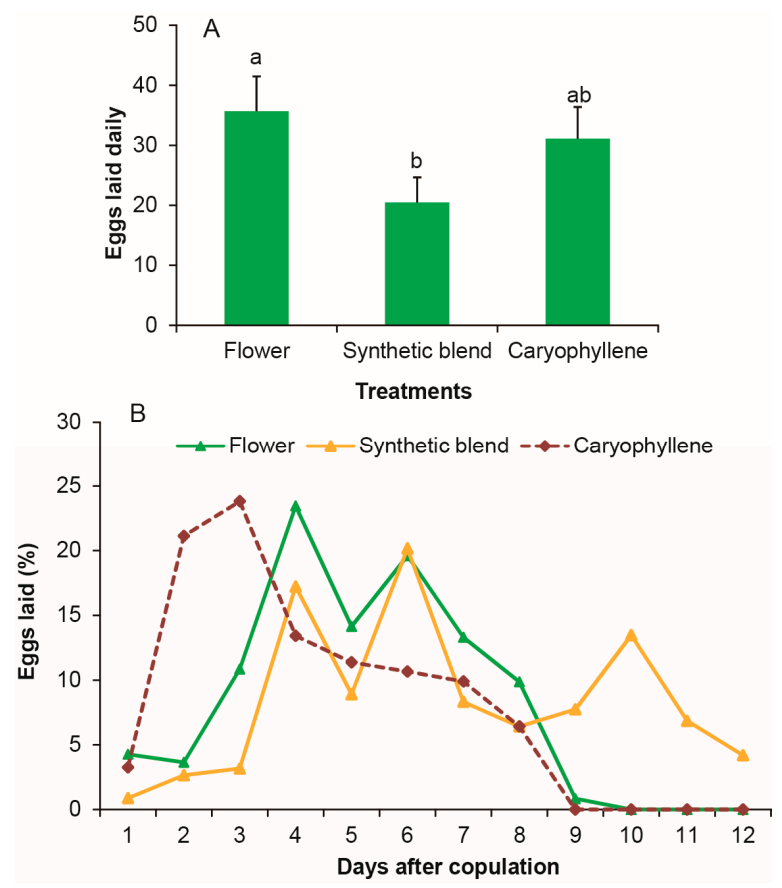

Figure 6. Effect of caryophyllene on oviposition of $M$. vitrata as strong as flower. (A) The number of eggs laid per female per day. (B) The number of eggs laid every day after copulation. Error bars signify SE. Significance among different volatiles indicated by lower case letters. Different letter means significant difference ( $p<0.05$, one-way ANOVA with Duncan' test). 


\subsection{Dose-Response Relationship for $\beta$-Caryophyllene as an Oviposition Stimulus}

The response elicited by $\beta$-caryophyllene in the oviposition bioassay was dose-dependent, in agreement with the EAG results. Significantly more eggs were laid per day in the presence of $\beta$-caryophyllene with a $10^{-1}$ concentration compared with that with $10^{-3}$ or $10^{-5}$ concentrations $(p \leq 0.028)$, but the number of eggs laid in a $10^{-5}$ concentration was significantly greater than that in the control group (paraffin oil) (Figure 7A, $p<0.001$ ). Interestingly, unmated females laid some eggs in response to $\beta$-caryophyllene (Figure $7 \mathrm{~B}, p<0.001$ ).
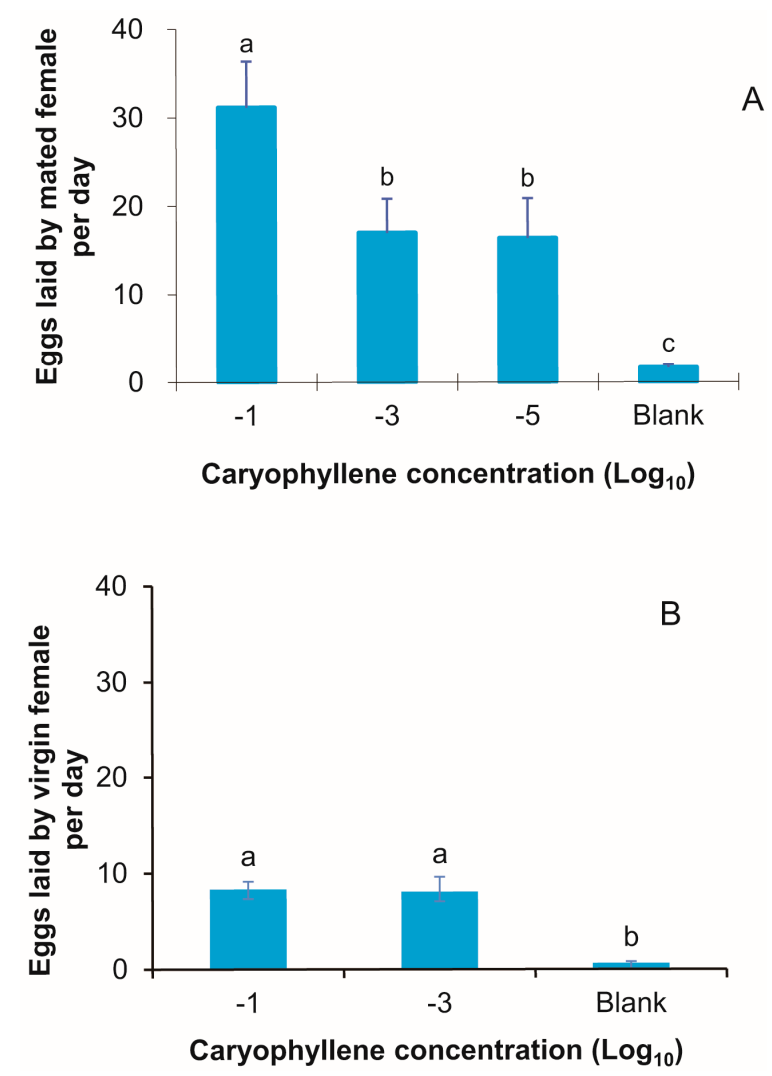

Figure 7. Effect of caryophyllene dosage on oviposition of mated (A) and unmated (B) M. vitrata elicited by $20 \mu \mathrm{L}$ of a paraffin oil solution of caryophyllene applied to paper. Error bars signify SE. Significance among different volatiles indicated by lower case letters. Different letter means significant difference ( $p<0.05$, one-way ANOVA with Duncan' test).

\subsection{Roles of Olfaction and Gustation in the Mediation of the Floral Volatile Oviposition Stimulus}

After being stimulated by $\beta$-caryophyllene with a $10^{-1}$ concentration, intact females with access to treated filter paper laid about the same number of eggs as intact females without access to treated filter paper (without contact, $p=0.528$ ), but laid significantly more eggs than females lacking antennae and with access to treated filter paper $(p=0.04)$ (Figure 8$)$. When denied access to treated filter paper, moths without antennae laid significantly fewer eggs than moths with antennae or/and with access to treated filter paper $(p \leq 0.01)$. In addition, females without antennae and access to treated filter paper laid no more eggs than intact females stimulated with paraffin oil (the control group, $p=0.314$ ) (Figure 8). 

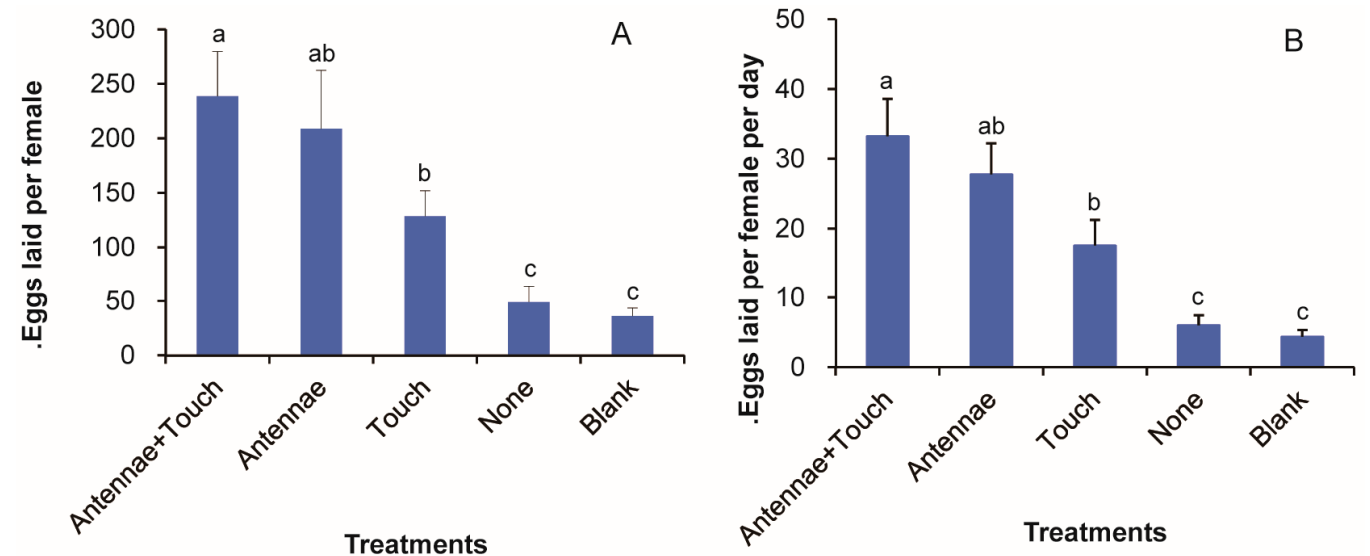

Figure 8. Testing the effect of antennal ablation and access to the odor source on oviposition of M. vitrata elicited by $20 \mu \mathrm{L}$ of a $10 \%$ paraffin oil solution of caryophyllene applied to paper. Antennae + Touch $=$ female with intact antennae and with access to treated filter paper; Antennae $=$ intact females responding to treated filter paper confined in ventilated tube; Touch = females lacking antennae with access to treated filter paper; None $=$ Females without antennae responding to treated filter paper confined in ventilated tube; Blank = filter paper with paraffin oil. Error bars signify SE. Significance among different volatiles indicated by lower case letters. Different letter means significant difference $(p<0.05$, one-way ANOVA with Duncan' test).

\section{Discussion}

Insect egg deposition is the start of the establishment of a new herbivore generation. Newly hatched larvae of many insects are relatively immobile and depend on the judicious behavior of their mother to find the best source of food for their successful growth and development. Female moths typically lay eggs on the larva host. The larvae of $M$. vitrata feed on the flower buds, flowers, and pods of $V$. unguiculata $[13,40,41]$. The incidence of $M$. vitrata larvae increases with the initiation of flowering. Maximum M. vitrata population is observed during flowering, and most 1st and 2nd instar larvae are observed on flowers [42-44]. In our bioassay, whole flowers of V. unguiculata strongly stimulated oviposition of the bean pod borer.

Linalool, $\beta$-caryophyllene, geraniol, and Z3-C6:Ac are common floral volatiles and have been found in many genera of family Fabaceae, such as genera Lathyrus, Lupinus, Medicago, Robinia, and Trifolium [45-48]. Each of these compounds elicited dose-dependent electrophysiological responses in the antennae of female $M$. vitrata. Although longifolene was not found in flowers of the family in former studies, it was found in our experiments. The antennae of female $M$. vitrata responded to longifolene in the electrophysiological test.

Several studies have shown that the production of $\beta$-caryophyllene, a sesquiterpene increased through herbivore feeding in cotton [49] and bean [50], and by egg deposition in leguminous plants [51] and elm [52] to attract parasitoids of herbivore. Some predators, such as the harlequin ladybird also use it as a cue to locate prey and oviposition sites [53,54]. Beta-caryophyllene was also the attractant for some herbivorous insects such as the weevil [55] and the damson hop aphid [56]. In our study, $\beta$-caryophyllene was the most active oviposition stimulant of $M$. vitrata among the tested floral volatiles. Beta-caryophyllene alone stimulated oviposition as strongly as the intact flowers. Its oviposition stimulation was faster than flowers, and it elicited a dose-dependent oviposition response. The oviposition stimulation of $\beta$-caryophyllene was also found in Cameraria ohridella, where the females' oviposition increased through the chemicals released from the blossoms of the host tree [57]. In fact, oviposition behavior influenced by one or several common plant volatile compounds has been found in many insects, such as the Mediterranean fruit fly Ceratitis capitata [58,59], and the moths Helicoverpa armigera, Spodoptera litura, and Chilo partellus [60,61]. For example, common plant volatile compounds (Z)-3-hexenyl acetate, (3E)-4,8-dimethyl-1,3,7-nonatriene, and linalool were 
found to significantly enhance female oviposition of Chrysopa phyllochroma [62]. Manduca sexta females oviposited more on plants emitting (-)-linalool (alone or in mixtures) than control plants, while plants emitting (+)-linalool (alone or in mixtures) were less preferred than control plants [63]. By contrast with $\beta$-caryophyllene, the sesquiterpene longifolene was not significantly active in the oviposition bioassay when presented singly. The antennal response of female $M$. vitrata to longifolene in the electrophysiological test might encode specificity, as it permits females to discriminate between the non-host plant and host plant. (Z)-3-Hexenyl acetate is one of the most abundant volatiles released by $V$. unguiculata, comprising $28.8 \%$ of volatiles collected from 3-week-old cowpea plants [64] and $40 \%$ of the volatiles emitted by their leaves, a proportion that increases rapidly if the leaves are injured [65]. The release of (Z)-3-hexenyl acetate by $V$. unguiculata leaves is consistent with their activity in our oviposition bioassay.

M. vitrata is a nocturnal moth and its behavior, including feeding and mating, has always been found during nighttime [66]. In our study, after being exposed to host floral volatiles, females laid significantly more eggs at night, and the number of eggs increased 14 times for $\beta$-caryophyllene treatment. The stimulation of oviposition during the night was in accordance to the nocturnal habitats of $M$. vitrata moth. In nature, blossoms of $V$. unguiculata are found between the hours of 6:00-12:00 a.m. [67]. The blossom of $V$. unguiculata was seemingly inconsistent with the oviposition time of $M$. vitrata. In fact, the blooming of $V$. unguiculata flower was gradually accomplished from 9:00 p.m. in our observation. In the process of $V$. unguiculata flower blooming, floral volatiles might be found by nocturnal moth, including $M$. vitrata. Female $M$. vitrata laid eggs during the day. The emergence of $M$. vitrata moth was also found during the day but the number of moths that emerged during this period was only about $20 \%$ [66]. Diurnal behaviors were also found in other nocturnal moths. Mating and oviposition during the day were found in Plutella xylostella in the winter [68]. Throughout the day, Lymantria dispar virgin females exhibit calling behavior to attract males [69]. The number of eggs laid by female $M$. vitrata during the day was not significantly increased with host floral volatile treatment. The exact mechanism of this phenomenon is unknown, but it was able to shut down the recognition of moth to the floral volatiles during the day. A diurnal rhythm for expression of olfactory genes had been found in many nocturnal moths. For example, gene expression of OR11, OR18, OrCo, ABP2, OBP1, and PBP1 increased after light-off and peaked after four hours in Spodoptera exigua [70]. Beta-caryophyllene, linalool, geraniol, and (Z)-3-hexenyl acetate had oviposition stimulant activity for $M$. vitrata moths when they were active on their own, but all volatiles were common among non-hosts [31]. Oviposition stimulants might not be host-specific if host-specificity is determined by other cues during host location flights; rather, they should indicate the quality of the host plant [71] and allow oviposition to be synchronized with plants at the appropriate developmental stage. The decreased level of volatiles could have contributed to the low quality of the host plant and decreased the number of eggs that the female laid. Other moths were also responsive to multiple volatiles as oviposition stimulants [72,73]. Although the number of eggs under $10^{-1} \beta$-caryophyllene stimulus was the same as that of the flower in our study, we cannot conclude that $\beta$-caryophyllene alone has the same stimulation as does an entire flower in nature, as the active concentration of $\beta$-caryophyllene is narrow. When the concentration of $\beta$-caryophyllene was decreased, the number of eggs was dramatically decreased and was much lower than the number elicited by the flower, suggesting that additional volatiles from the host plant may be active.

There were examples where synergy occurred in the response to multiple volatiles as in Heliothis armigera [22], and where it did not occur, as in Cochylis hospes [27]. The presence of synergy in response to multiple volatiles was likely to indicate the unreliability of single volatile cues as the indicators of the plant quality required by the insect for rearing the next generation. In M. vitrata, there appeared to be an absence of synergy between oviposition stimulants with the same volume, which might have resulted from the synthetic blends following the unnatural composition. The synergy between oviposition stimulants might be confirmed by tests with volatiles in natural proportions. 
The use of more than one volatile as an oviposition cue was likely to be an advantage even for an oligophagous insect, as different hosts might release different volatiles in different qualities.

Intact $M$. vitrata responded to oviposition stimuli whether or not they could contact the source of the volatiles. We believe this is the first demonstration in a moth where oviposition behavior was able to be initiated only by host-plant floral volatiles sensed by olfaction. Olfactory detection of plant volatiles in M. vitrata was most likely associated with the sensilla of the distal flagellar segments of the antenna, which is important in mediating the oviposition stimulus provided by the host plant [74]. Few plant volatile secondary metabolites have been recognized by gustatory receptors on the insect's ovipositor, tarsi, or mouth parts [1,6]. In our studies, female $M$. vitrata were able to sense the volatile without antennae. There is a mediating role for receptors not on the antennae, and these non-antennal receptors for the oviposition stimulus are gustatory. Gustatory receptors for oviposition stimulants may be located on the tarsi where, in the swallowtail butterfly Atrophaneura alcinous, the binding proteins involved in the recognition of oviposition stimulants had recently been characterized [75]. In recent findings, the wing gustatory hair and tracheal architectures of Drosophila had been found capable of trapping volatile molecules from the environment [76]. We found evidence that either olfaction or gustation was sufficient to mediate an oviposition response to $V$. unguiculata floral volatiles. The sufficiency of olfaction in mediating the oviposition stimulus for $M$. vitrata contrasted with P. xylostella which, when given olfactory but not gustatory stimuli, did not oviposit, but when given gustatory stimuli laid similar numbers of eggs as when given both olfactory and gustatory cues [77]. The use of both olfactory and gustatory cues for oviposition perhaps in part explains why not all eggs were laid on flowers, which is the preferred location for the first and second instar larvae [43], but were scattered on the leaves, flowers, stems, and pods [40]. This oviposition behavior could be attributed to adaptation. If floral oviposition cues are perceived over a longer range by natural enemies, and newly eclosed larvae are capable of moving to the flowers, then females scattering eggs more widely on the plant might reduce overall predation pressure on their progeny.

We showed that certain floral volatiles alone could elicit the oviposition of $M$. vitrata, which might open doors for future research into semiochemical-based control methods for this widespread pest [24]. The effectiveness of a single component, $\beta$-caryophyllene, which is widely expressed by non-host plants, could be exploited as part of a push-pull strategy in which oviposition onto $\beta$-caryophyllene-expressing non-host plants provides a sink for the $M$. vitrata population. Alternatively, it might be possible to block the olfaction of the volatiles through artificial application of inhibitory compounds, or to alter the phenology of volatile release by the host plant so that moth oviposition lose its synchrony with flowering.

\section{Conclusions}

The bean pod borer, Maruca vitrata (Fabricius) (Lepidoptera, Crambidae), is a serious pest of grain legumes in the tropics and subtropics. The larva is a borer in flower buds, flowers, and developing bean pods, making it difficult to manage the pest with chemical insecticides. In our study, $\beta$-caryophyllene, a common volatile of plant flowers was found as the most active stimulus in the oviposition of $M$. vitrata among the five compounds tested, as effective as the flower of $V$. unguiculata. Either olfaction or gustation was sufficient to mediate the oviposition response to $\beta$-caryophyllene. Our results shed some light on the mechanism of insect oviposition and might open doors for future research into semiochemically based control methods for this widespread pest.

Acknowledgments: We are grateful to Shizhong Xu (University of California Riverside) for his help with statistical analysis, Caroline Du (University of California Irvine) for her help in the English editing, and Deqin Lin for his technical work. This work was supported financially by the National Science Foundation of China (Grant No. 30871645) and Special Fund for Agro-scientific Research in the Public Interest in China (Grant No. 201203036) to Yong-Jun Du.

Author Contributions: Bo Feng and Yong-Jun Du conceived and designed the experiments; Bo Feng and Kai Qian performed the experiments; Bo Feng and Yong-Jun Du analyzed the data; Bo Feng and Kai Qian contributed reagents/materials/analysis tools; Bo Feng and Yong-Jun Du wrote the paper. 
Conflicts of Interest: The authors declare no conflict of interest.

\section{References}

1. Renwick, J.A.A.; Chew, F.S. Oviposition behavior in Lepidoptera. Annu. Rev. Entomol. 1994, 39, 377-400. [CrossRef]

2. Rojas, J.C.; Wyatt, T.D.; Birch, M.C. Flight and oviposition behavior toward different host plant species by the cabbage moth, Mamestra brassicae (L.) (Lepidoptera: Noctuidae). J. Insect Behav. 2000, 13, 247-254. [CrossRef]

3. Thompson, J.N.; Pellmyr, O. Evolution of oviposition behavior and host preference in Lepidoptera. Annu. Rev. Entomol. 1991, 36, 65-89. [CrossRef]

4. Raguso, R.A. Wake up and smell the roses: The ecology and evolution of floral scent. Annu. Rev. Ecol. Evol. Syst. 2008, 39, 549-569. [CrossRef]

5. Riffell, J.A.; Alarcón, R.; Abrell, L.; Davidowitz, G.; Bronstein, J.L.; Hildebrand, J.G. Behavioral consequences of innate preferences and olfactory learning in hawkmoth-flower interactions. Proc. Natl. Acad. Sci. USA 2008, 105, 3404-3409. [CrossRef] [PubMed]

6. Du, Y.J.; Loon, J.J.A.V.; Renwick, J.A.A. Contact chemoreception of oviposition-stimulating glucosinolates and an oviposition-deterrent cardenolide in two subspecies of Pieris napi. Physiol. Entomol. 1995, 20, 164-174. [CrossRef]

7. Hughes, P.R.; Renwick, J.A.A.; Lopez, K.D. New oviposition stimulants for the diamondback moth in cabbage. Entomol. Exp. Appl. 1997, 85, 281-283. [CrossRef]

8. Lee, H.S.; Hieu, T.; Ahn, Y.J. Oviposition-stimulating activity of (E)-capsaicin identified in Capsicum annuum fruit and related compounds towards Helicoverpa assulta (Lepidoptera: Noctuidae). Chemoecology 2006, 16, 153-157. [CrossRef]

9. Maher, N.; Thiery, D. Daphne gnidium, a possible native host plant of the European grapevine moth Lobesia botrana, stimulates its oviposition. Is a host shift relevant? Chemoecology 2006, 16, 135-144. [CrossRef]

10. Macel, M.; Vrieling, K.; Macel, M.; Vrieling, K. Pyrrolizidine alkaloids as oviposition stimulants for the cinnabar moth, Tyria jacobaeae. J. Chem. Ecol. 2003, 29, 1435-1446. [CrossRef] [PubMed]

11. Mozuraitis, R.; Stranden, M.; Ramirez, M.I.; Borg-Karlson, A.K.; Mustaparta, H. (-)-Germacrene D increases attraction and oviposition by the tobacco budworm moth Heliothis virescens. Chem. Senses 2002, 27, 505-509. [CrossRef] [PubMed]

12. Durairaj, C.; Shanower, T.G.; Bhagwat, V.R.; Khan, M.I.; Dodia, D.A. Relationship between Helicoverpa armigera Hubner and Maruca vitrata (Geyer) abundance, damage and yield loss in short-duration pigeonpeas. Int. J. Trop. Insect Sci. 2003, 23, 251-258. [CrossRef]

13. Sharma, H.C.; Franzmann, B.A. Biology of the legume pod borer, Maruca vitrata (Fabricius) and its damage to pigeonpea and Adzuki bean. Int. J. Trop. Insect Sci. 2000, 20, 99-108. [CrossRef]

14. Atachi, P.; Dannon, E.A.; Arodokoun, Y.D.; Tamo, M. Distribution and sampling of Maruca vitrata (Fabricius) (Lep., Pyralidae) larvae on Lonchocarpus sericeus (Poir) H.B. and K. J. Appl. Entomol. 2002, 126, 188-193. [CrossRef]

15. Gopali, J.B.; Teggelli, R.; Mannur, D.M.; Yelshetty, S. Web-forming lepidopteran, Maruca vitrata (Geyer): An emerging and destructive pest in pigeonpea. Karnataka J. Agric. Sci. 2010, 23, 35-38.

16. Wäckers, F.L.; Romeis, J.; van Rijn, P. Nectar and pollen feeding by insect herbivores and implications for multitrophic interactions. Annu. Rev. Entomol. 2006, 52, 301-323. [CrossRef] [PubMed]

17. Bottenberg, H.; Tam, M.; Singh, B.B. Occurrence of phytophagous insects on wild Vigna sp. and cultivated cowpea: Comparing the relative importance of host-plant resistance and millet intercropping. Agric. Ecosyst. Environ. 1998, 70, 217-229. [CrossRef]

18. Shuttleworth, A.; Johnson, S.D. A key role for floral scent in a wasp-pollination system in Eucomis (Hyacinthaceae). Ann. Bot. 2009, 103, 715-725. [CrossRef] [PubMed]

19. Beerwinkle, K.R.; Shaver, T.N.; Lopez, J.D. Field observations of adult emergence and feeding behavior of Helicoverpa zea (Lepidoptera: Noctuidae) on dallisgrass ergot honeydew. Environ. Entomol. 1993, 22, 554-558. [CrossRef]

20. Gabel, B.; Thiéry, D.; Suchy, V.; Marion-Poll, F.; Hradsky, P.; Farkas, P. Floral volatiles of Tanacetum vulgare L. attractive to Lobesia botrana den. et schiff. females. J. Chem. Ecol. 1992, 18, 693-701. [CrossRef] [PubMed] 
21. Rajapakse, C.N.K.; Walter, G.H. Polyphagy and primary host plants: Oviposition preference versus larval performance in the lepidopteran pest Helicoverpa armigera. Arthropod-Plant Interact. 2007, 1, 17-26. [CrossRef]

22. Jallow, M.F.A.; Zalucki, M.P.; Fitt, G.P. Role of chemical cues from cotton in mediating host selection and oviposition behaviour in Helicoverpa armigera (Hubner) (Lepidoptera: Noctuidae). Aust. J. Entomol. 1999, 38, 359-366. [CrossRef]

23. Mitchell, E.R.; Tingle, F.C.; Heath, R.R. Flight activity of Heliothis virescens (F.) females (Lepidoptera, Noctuidae) with reference to host-plant volatiles. J. Chem. Ecol. 1991, 17, 259-266. [CrossRef] [PubMed]

24. Cook, S.M.; Rasmussen, H.B.; Birkett, M.A.; Murray, D.A.; Pye, B.J.; Watts, N.P.; Williams, I.H. Behavioural and chemical ecology underlying the success of turnip rape (Brassica rapa) trap crops in protecting oilseed rape (Brassica napus) from the pollen beetle (Meligethes aeneus). Arthropod-Plant Interact. 2007, 1, 57-67. [CrossRef]

25. Atachi, P.; Hountondji, F.C.C. Olfactory responses of Maruca vitrata (Fabricius) larvae to reproductive parts of different varieties of cowpea, Vigna unguiculata (L.) Walp. Insect Sci. Appl. 2000, 20, 117-121. [CrossRef]

26. Halder, J.; Srinivasan, S.; Muralikrishna, T. Biochemical basis of resistance to spotted pod borer, Maruca vitrata (Geyer) in Mungbean. J. Entomol. Res. 2006, 30, 313-316.

27. Morris, B.D.; Foster, S.P.; Grugel, S.; Charlet, L.D. Isolation of the diterpenoids, ent-kauran-16alpha-ol and ent-atisan-16alpha-ol, from sunflowers, as oviposition stimulants for the banded sunflower moth, Cochylis hospes. J. Chem. Ecol. 2005, 31, 89-102. [CrossRef] [PubMed]

28. Morris, B.D.; Charlet, L.D.; Foster, S.P. Isolation of three diterpenoid acids from sunflowers, as oviposition stimulants for the banded sunflower moth, Cochylis hospes. J. Chem. Ecol. 2009, 35, 50-57. [CrossRef] [PubMed]

29. Bendera, M.; Ekesi, S.; Ndung'u, M.; Srinivasan, R.; Torto, B. A major host plant volatile, 1-octen-3-ol, contributes to mating in the legume pod borer, Maruca vitrata (Fabricius) (Lepidoptera: Crambidae). Naturwissenschaften 2015, 102, 47. [CrossRef] [PubMed]

30. Ager, C.A. Analysis of Chemical Composition of Cowpea Floral Volatiles and Nectar. Master's Thesis, Kenyatta University, Kahawa, November 2009.

31. Knudsen, J.; Eriksson, R.; Gershenzon, J.; Ståhl, B. Diversity and distribution of floral scent. Bot. Rev. 2006, 72, 1-120. [CrossRef]

32. Eltz, T.; Ayasse, M.; Lunau, K. Species-specific antennal responses to tibial fragrances by male orchid bees. J. Chem. Ecol. 2006, 32, 71-79. [CrossRef] [PubMed]

33. Parachnowitsch, A.L.; Raguso, R.A.; Kessler, A. Phenotypic selection to increase floral scent emission, but not flower size or colour in bee-pollinated Penstemon digitalis. New Phytol. 2012, 195, 667-675. [CrossRef] [PubMed]

34. Galizia, C.G.; Kunze, J.; Gumbert, A.; Borg-Karlson, A.-K.; Sachse, S.; Markl, C.; Menzel, R. Relationship of visual and olfactory signal parameters in a food-deceptive flower mimicry system. Behav. Ecol. 2005, 16, 159-168. [CrossRef]

35. Koschier, E.; De Kogel, W.; Visser, J.H. Assessing the attractiveness of volatile plant compounds to western flower thrips Frankliniella occidentalis. J. Chem. Ecol. 2000, 26, 2643-2655. [CrossRef]

36. Ruther, J. Male-biassed response of garden chafer, Phyllopertha horticola L., to leaf alcohol and attraction of both sexes to floral plant volatiles. Chemoecology 2004, 14, 187-192. [CrossRef]

37. Kessler, D.; Baldwin, I.T. Making sense of nectar scents: The effects of nectar secondary metabolites on floral visitors of Nicotiana attenuata. Plant J. 2007, 49, 840-854. [CrossRef] [PubMed]

38. Ke, L.-D.; Fang, J.-L.; Li, Z.-J. Bionomics and control of the legume pod borer Maruca testulalis (Geyer). Acta Entomol. Sin. 1985, 28, 51-59.

39. Yan, F.; Du, Y.; Han, X. A comparative study on the electroantenogram responses of three aphid species to plant volatiles. Insect Sci. 1994, 1, 53-66. [CrossRef]

40. Oghiakhe, S. Effect of cowpea cultivar, plant part and growth phenology on oviposition behaviour of the legume pod borer, Maruca testulalis Geyer (Lep., Pyralidae). J. Appl. Entomol. 1996, 120, 549-553. [CrossRef]

41. Sharma, H.C. Bionomics, host plant resistance, and management of the legume pod borer, Maruca vitrata-A review. Crop Prot. 1998, 17, 373-386. [CrossRef]

42. Imosanen; Singh, H.K.B. Incidence of Helicoverpa armigera (Hub.) and Maruca vitrata (Geyer) on pigeonpea under Medzephema conditions of Nagaland. J. Appl. Zool. Res. 2005, 16, 85-86. 
43. Liao, C.T.; Lin, C.S. Occurrence of the legume pod borer, Maruca testulalis Geyer (Lepidoptera: Pyralidae) on cowpea (Vigna nguiculata Walp) and its insecticides application trial. Plant Prot. Bull. 2000, 42, 213-222.

44. Sonune, V.R.; Bharodia, R.K.; Jethva, D.M.; Dabhade, P.L. Seasonal incidence of spotted pod borer, Maruca testulalis (Geyer) on blackgram. Legum. Res. 2010, 33, 61-63.

45. Porter, A.E.A.; Griffiths, D.W.; Robertson, G.W.; Sexton, R. Floral volatiles of the sweet pea Lathyrus odoratus. Phytochemistry 1999, 51, 211-214. [CrossRef]

46. Light, D.M.; Kamm, J.A.; Buttery, R.G. Electroantennogram response of alfalfa seed chalcid, Bruchophagus roddi (Hymenoptera: Eurytomidae) to host- and nonhost-plant volatiles. J. Chem. Ecol. 1992, 18, 333-352. [CrossRef] [PubMed]

47. Kamdem, D.P.; Gruber, K.; Barkman, T.; Gage, D.A. Characterization of black locust floral fragrance. J. Essent. Oil Res. 1994, 6, 199-200. [CrossRef]

48. Dobson, H.E.M.; Groth, I.; Bergström, G. Pollen advertisement: Chemical contrasts between wholeflower and pollen odors. Am. J. Bot. 1996, 83, 877-885. [CrossRef]

49. Turlings, T.; Benrey, B. Effects of plant metabolites on the behavior and development of parasitic wasps. Ecoscience 1998, 5, 321-333. [CrossRef]

50. Verheggen, F.; Arnaud, L.; Bartram, S.; Gohy, M.; Haubruge, E. Aphid and plant volatiles induce oviposition in an aphidophagous hoverfly. J. Chem. Ecol. 2008, 34, 301-307. [CrossRef] [PubMed]

51. Colazza, S.; McElfresh, J.S.; Millar, J. Identification of volatile synomones, induced by Nezara viridula feeding and oviposition on bean spp., that attract the egg parasitoid Trissolcus basalis. J. Chem. Ecol. 2004, 30, 945-964. [CrossRef] [PubMed]

52. Wegener, R.; Schulz, S.; Meiners, T.; Hadwich, K.; Hilker, M. Analysis of volatiles induced by oviposition of elm leaf beetle Xanthogaleruca luteola on Ulmus minor. J. Chem. Ecol. 2001, 27, 499-515. [CrossRef] [PubMed]

53. Alhmedi, A.; Haubruge, E.; Francis, F. Identification of limonene as a potential kairomone of the harlequin ladybird Harmonia axyridis (Coleoptera: Coccinellidae). Eur. J. Entomol. 2010, 107, 541-548. [CrossRef]

54. Verheggen, F.; Fagel, Q.; Heuskin, S.; Lognay, G.; Francis, F.; Haubruge, E. Electrophysiological and behavioral responses of the multicolored Asian lady beetle, Harmonia axyridis pallas, to sesquiterpene semiochemicals. J. Chem. Ecol. 2007, 33, 2148-2155. [CrossRef] [PubMed]

55. Bichão, H.; Borg-Karlson, A.K.; Araújo, J.; Mustaparta, H. Identification of plant odours activating receptor neurones in the weevil Pissodes notatus F. (Coleoptera, Curculionidae). J. Comp. Physiol. A 2003, 189, $203-212$.

56. Campbell, C.A.M.; Pettersson, J.; Pickett, J.A.; Wadhams, L.J.; Woodcock, C.M. Spring migration of damson-hop aphid, Phorodon humuli (Homoptera, Aphididae), and summer host plant-derived semiochemicals released on feeding. J. Chem. Ecol. 1993, 19, 1569-1576. [CrossRef] [PubMed]

57. Johne, A.B.; Sprauer, S.; Weißbecker, B.; Schütz, S. Influence of flower odor compounds on oviposition of the horse chestnut leaf miner Cameraria ohridella (Deschka and Dimic). Mitt. Dtsch. Ges. Allg. Angew. Entomol. 2006, 14, 355-360.

58. Furtado, R.; Baptista, J.; Lima, E.; Paiva, L.; Barroso, J.G.; Rosa, J.S.; Oliveira, L. Chemical composition and biological activities of Laurus essential oils from different Macaronesian Islands. Biochem. Syst. Ecol. 2014, 55, 333-341. [CrossRef]

59. Ioannou, C.S.; Papadopoulos, N.T.; Kouloussis, N.A.; Tananaki, C.I.; Katsoyannos, B.I. Essential oils of citrus fruit stimulate oviposition in the Mediterranean fruit fly Ceratitis capitata (Diptera: Tephritidae). Physiol. Entomol. 2012, 37, 330-339. [CrossRef]

60. Koul, O.; Singh, R.; Kaur, B.; Kanda, D. Comparative study on the behavioral response and acute toxicity of some essential oil compounds and their binary mixtures to larvae of Helicoverpa armigera, Spodoptera litura and Chilo partellus. Ind. Crop. Prod. 2013, 49, 428-436. [CrossRef]

61. McCallum, E.J.; Cunningham, J.P.; Lucker, J.; Zalucki, M.P.; De Voss, J.J.; Botella, J.R. Increased plant volatile production affects oviposition, but not larval development, in the moth Helicoverpa armigera. J. Exp. Biol. 2011, 214, 3672-3677. [CrossRef] [PubMed]

62. Xu, X.X.; Cai, X.M.; Bian, L.; Luo, Z.X.; Xin, Z.J.; Chen, Z.M. Electrophysiological and behavioral responses of Chrysopa phyllochroma (Neuroptera: Chrysopidae) to plant volatiles. Environ. Entomol. 2015, 44, 1425-1433. [CrossRef] [PubMed]

63. Reisenman, C.E.; Riffell, J.A.; Bernays, E.A.; Hildebrand, J.G. Antagonistic effects of floral scent in an insect-plant interaction. Proc. R. Soc. B Biol. Sci. 2010, 277, 2371-2379. [CrossRef] [PubMed] 
64. Lwande, W.; McDowell, P.G.; Amiani, H.; Amoke, P. Analysis of airborne volatiles of cowpea. Phytochemistry 1989, 28, 421-423. [CrossRef]

65. Van Den Boom, C.E.M.; Van Beek, T.A.; Posthumus, M.A.; De Groot, A.; Dicke, M. Qualitative and quantitative variation among volatile profiles induced by Tetranychus urticae feeding on plants from various families. J. Chem. Ecol. 2004, 30, 69-89. [CrossRef] [PubMed]

66. Lu, P.F.; Qiao, H.L.; Wang, X.P.; Zhou, X.M.; Wang, X.Q.; Lei, C.L. Adult behavior and circadian rhythm of sex pheromone production and release of the legume pod borer, Maruca vitrata (Fabricius) (Lepidoptera: Pyralidae). Acta Entomol. Sin. 2007, 50, 335-342.

67. Ige, O.E.; Olotuah, O.F.; Akerele, V. Floral biology and pollination ecology of cowpea (Vigna unguiculata L. Walp). Mod. Appl. Sci. 2011, 5, 74-82.

68. Uematsu, H.; Yoshikawa, K. Changes in copulation and oviposition time of the diamondback moth, Plutella xylostella (Lepidoptera: Plutellidae). Jpn. J. Appl. Entomol. Zool. 2002, 46, 81-87. [CrossRef]

69. Iwaizumi, R.; Arakawa, K.; Koshio, C. Nocturnal flight activities of the female Asian gypsy moth, Lymantria dispar (Linnaeus) (Lepidoptera: Lymantriidae). Appl. Entomol. Zool. 2010, 45, 121-128. [CrossRef]

70. Wan, X.L.; Qian, K.; Du, Y.J. Synthetic pheromones and plant volatiles alter the expression of chemosensory genes in Spodoptera exigua. Sci. Rep. 2015, 5. [CrossRef] [PubMed]

71. Hilker, M.; Meiners, T. Plants and insect eggs: How do they affect each other? Phytochemistry 2011, 72, 1612-1623. [CrossRef] [PubMed]

72. Magalhaes, S.T.; Guedes, R.N.; Demuner, A.J.; Lima, E.R. Effect of coffee alkaloids and phenolics on egg-laying by the coffee leaf miner Leucoptera coffeella. Bull. Entomol. Res. 2008, 98, 483-489. [CrossRef] [PubMed]

73. Fatzinger, C.W.; Merkel, E.P. Oviposition and feeding preferences of the southern pine coneworm (Lepidoptera: Pyralidae) for different host-plant materials and observations on monoterpenes as an oviposition stimulant. J. Chem. Ecol. 1985, 11, 689-699. [CrossRef] [PubMed]

74. Wang, X.; Xu, J.; Shen, Y.-L.; Liu, F.-Y.; Du, Y.-J. Electroantennogram responses of Maruca testulalis (Lepidoptera: Pyralidae) to plant volatiles and sex pheromone. Yingyong Shengtai Xuebao 2009, 20, 1973-1979. [PubMed]

75. Tsuchihara, K.; Hisatomi, O.; Tokunaga, F.; Asaoka, K. An oviposition stimulant binding protein in a butterfly: Immunohistochemical localization and electrophysiological responses to plant compounds. Commun. Integr. Biol. 2009, 2, 356-358. [CrossRef] [PubMed]

76. Valmalette, J.C.; Raad, H.; Qiu, N.; Ohara, S.; Capovilla, M.; Robichon, A. Nano-architecture of gustatory chemosensory bristles and trachea in Drosophila wings. Sci. Rep. 2015, 5, 14198. [CrossRef] [PubMed]

77. Justus, K.A.; Mitchell, B.K. Oviposition site selection by the diamondback moth, Plutella xylostella (L.) (Lepidoptera: Plutellidae). J. Insect Behav. 1996, 9, 887-898. [CrossRef] 